\title{
THE SOUNDSCAPE IN THE REPLICA OF THE CERÉN TEMAZCAL
}

\author{
Payson Sheets $\mathbb{1}^{\mathrm{a}}$ and Robert Mahoney \\ aDepartment of Anthropology, University of Colorado, Boulder, Colorado 80309 \\ b310 Balsam Avenue, Boulder, Colorado 80304
}

\begin{abstract}
Archaeologists have relied almost exclusively upon sight among the five human senses to investigate architecture, features, and artifacts. In recent decades researchers have explored how ancient people may have experienced sound, because it was an essential component of lived experiences in ancient societies. Natural and culturally constructed spaces had acoustical properties that enhanced social, political, economic, and ritual events. This article investigates through the lens of archaeoacoustics the large domed earthen temazcal that residents constructed at Joya de Cerén during the seventh century A.D. Its uniqueness at this Classic-period Maya village in El Salvador has attracted considerable interest due to its exceptional preservation and distinct shape. Fortunately, in 2012, architects were able to construct a precise replica for public access. Through the years, visitors entering the replica have noted how significantly their voices were altered, once inside. To evaluate scientifically these observations, two recordings of sound were made and analyzed acoustically. The earthen dome morphology causes "preferred frequencies" to be sustained for a long time, while nonfavored frequencies diminish quickly. The predominant resonance is at 64 hertz, a tone so low that basso profundo singers can barely achieve it. The internal morphology greatly accentuates voices of mature males, but not those with higher pitches, such as mature females or children. The acoustical environment may have been utilized by men for divination, education, curing, rites of passage, and other functions, some of which have not been previously considered. The nature of the lived experience in a socially charged performance space is explored here with new insights regarding how the sweatbath was vital to all in the community.
\end{abstract}

\section{INTRODUCTION}

Acoustic studies in archaeology are being incorporated into research at an increasing rate to further contribute to our knowledge of ancient lifeways. In this article, we contribute to the field of archaeoacoustics through the analysis of the acoustical properties of a replica of a domed earthen temazcal (or sweatbath), precisely modeled after the ancient sweatbath uncovered at the seventh century A.D. Classic-period Maya village of Joya de Cerén, El Salvador. First, we briefly review the field of archaeoacoustics and then contextualize the Cerén temazcal by examining other ancient Maya sweatbaths and their presumed functions. A short discussion of the ancient village of Cerén and its households provides the reader with the social setting in which this temazcal operated. Details of the original sweatbath are presented regarding its construction, form, burial, and excavation. Information about the replica and the initial acoustic study set the stage for understanding the sound recordings and detailed acoustical analysis. The findings of this study widen our knowledge of how an ancient community may have utilized a sweatbath to the advantage of all members.

\section{ACOUSTIC STUDIES IN ARCHAEOLOGY}

Archaeologists from the beginning and continuing to today have emphasized sight over other human senses of touch, hearing,

E-mail correspondence to: sheetsp@colorado.edu smell, and taste, as they have visually examined architecture, features, artifacts, and other items. The other senses largely have been ignored, with only occasional exceptions. The sense of touch is useful in lithic and ceramic analyses to physically handle objects and add to our knowledge of them. The sense of hearing has recently become of interest to scholars who are investigating how ancient people manipulated sound, or took advantage of the acoustic properties of natural and constructed features, a field of study called archaeoacoustics (Primeau and Witt 2018; Scarre and Lawson 2006). Soundscapes have been investigated in recent decades, ranging in size from musical instruments, small enclosed spaces, caves, and broad, open landscapes (Garza et al. 2008; Kolar 2017; Primeau and Witt 2018; Scarre 2006). Kolar (2017) provides a classic example of sonic research in ancient enclosed spaces at Chavín de Huantar, Peru. Primeau and Witt (2018) furnishes a case study of acoustic research in the broad landscape of Chaco Canyon in New Mexico.

Lubman's (1998) speculation regarding the echoes from the steps of the Castillo pyramid at Chichen Itza in Yucatan supplies an example at an intermediate scale. Houston and Taube (2000) ingeniously explore sight, sound, and smell among the Classicperiod Maya, by seeking the meanings and implications of the art and epigraphy. Small resonance chambers of Maya flutes and shell trumpets are the foci of Katz's (2018) recent dissertation. Triple-chambered flutes from Copan and Jaina are studied acoustically in the recent article by Zalaquett and Espino (2019). These authors state that the flute music should be considered a means of 
nonlinguistic communication facilitating contact with the supernatural domain, particularly in funerary ceremonies. Garza et al. (2008) provide other examples of formal-to-informal studies from the Maya realm, and they suggest standards for future studies of archaeoacoustics.

Adding the dimension of sound helps archaeologists to explore the nature of ancient lived experiences, and how sound may have contributed to a sense of place (Primeau and Witt 2018). People manipulated acoustics, or took advantage of natural features, in a wide variety of ways. According to Tilley (2008:41) "surfaces, according to their direction in relation to one another, inclination, texture, and degree of absorption will structure, reduce, or amplify sound; and auditory perception derives its basis from the flow of sounds through the landscape from one place to another, producing different acoustic properties."

\section{THE CERÉN TEMAZCAL REPLICA AND ACOUSTICS}

The objective of this article is to explore the micro-soundscape inside the replica of the temazcal (or sweatbath; terms used interchangeably here) at the Cerén archaeological site, El Salvador. The short walls, domed low ceiling, sound-reflective surfaces, and size of enclosure had significant acoustic effects on sounds generated inside the replica. Most of the gender-related literature on Maya sweatbaths focuses on women, as pregnancy and childbirth were treated by midwives inside the structure, and the structure was viewed as the womb of Mother Earth. The Cerén sweatbath presumably was used frequently for those female rites. We suggest from the results of our research, however, that mature males may have used the Cerén temazcal for numerous purposes. Archaeologists may have underestimated mature male activities in sweatbaths. The most notable resonant frequencies in the replica are quite low and thus emphasize mature male voices, but not female voices or those of children. It is probable that mature males exploited this acoustic phenomenon for curing, rites of passage, education, religious events, and other sociocultural occasions. The Cerén temazcal was so strikingly different from all other buildings in the village, and so architecturally challenging to build and maintain, that we suggest its male-associated acoustic effects were deliberate. All other buildings excavated at Cerén had thatch roofs, which would have absorbed sounds. Cerénians inside the temazcal would have experienced sound in a fundamentally different way compared to every other public or household structure in their village.

\section{MAYA SWEATBATHS}

\section{Architecture and Features: Common Elements}

The distribution of sweatbaths throughout Mesoamerica spans several time periods and various cultures, so it is no surprise that research on temezcales is abundant (e.g., Olson 2021). Here, we focus on the scholarship of Maya sweatbaths to contextualize the Cerén structure. Shaw (2015) provides an extensive summary of ancient-to-recent Maya sweatbaths, including information about distribution, dating, architecture, and functions. The ancient, largely Classic-period sweatbaths, have been documented at Quirigua, Chichen Itza, El Paraiso, Dzibilchaltun, Cuello, and Piedras Negras. Adding to the database, Shaw included a Terminal Classic sweatbath from her research at Yo'okop in the Yucatan (Shaw 2015:86-90). These lowland Maya sweatbaths were constructed of limestone masonry, presumably with stone corbel vaults. They did not have domed roofs that could have had the acoustic effects of the Cerén sweatbath, though it would be interesting to assess their sonic properties. The lowland sweatbaths had some features similar to Cerén (McKee 2002b), including sufficient seating area for many participants, central masonry fireboxes, ventilation holes to allow dense smoke to escape before utilization, and some exterior and interior benches. They also commonly had drainage features to allow excess water to exit the structure, and they feature thicker walls than ordinary buildings at those sites. A low ceiling to concentrate and retain heat and moisture was another commonly shared feature. Desantes (2014) also published an excellent architectural survey of Maya sweatbaths, including details of their internal features.

Shaw (2015) mentioned the plethora of sweatbaths at Piedras Negras, and Child (2006) examined and interpreted the eight monumental sweatbaths in considerable detail, building on scholarship in Cresson's (1938) classic article. Based on dimensions in Cresson's work (1938:89), the average interior size is $4.0 \mathrm{~m}$ in length by $2.6 \mathrm{~m}$ in width, or $10.7 \mathrm{~m}^{2}$ of interior space. From Houston's (1996:143) measurements of seven Piedras Negras sweatbaths, we calculate an average of $12.3 \mathrm{~m}^{2}$. His measurements for the Cerén sweatbath are not correct. It is perhaps surprisingly large for a small village, at $3.4 \times 3.4 \mathrm{~m}$ with $11.6 \mathrm{~m}^{2}$ of interior space. This amount of space was suitable for sitting, with the sole exception of the $45-\mathrm{cm}$ wide entrance, and the firebox. It could seat a dozen people without much crowding. Piedras Negras fireboxes differ from Cerén in a few aspects. At Piedras Negras they were built of cut limestone masonry into miniature vaults and placed against the back walls. The Cerén firebox is built of volcanic stones in clay (that fired hard with use) in the form of a miniature dome at the top, and was located in the center of the building. We suggest at both locations a symbolic microcosm-macrocosm relationship may have existed relating the firebox to the main structure.

A small sweatbath was discovered in a rural area almost a halfhour walk from the epicenter of Piedras Negras (Webster 2018). It was located just uphill from a two-structure household compound, in a small rockshelter that conveniently provided the back wall of the sweatbath. The three remaining walls had low stone foundations upon which walls of perishable materials were built to connect to the roof of the low rockshelter. Though lacking a firebox, residents burned rocks inside the enclosed structure to obtain heat. As it had only $2.7 \mathrm{~m}^{2}$ of interior space, only two or three people at a time could have made use of it (Webster 2018:5). From this tiny rural sweatbath, to the specimen at Cerén, to the monumental examples from Palenque and Piedras Negras, a broad spectrum of physical facilities were in use by the Classic Maya.

Other examples of sweatbaths come from the Maya Highlands. Two pre-Columbian sweatbaths were excavated decades ago in Guatemala. Ichon (1977) excavated one at the site of Los Cimientos, in the Quiche department, dating to the late Postclassic. It was built into a terrace with numerous other buildings, which perhaps is the reason for its elongated rectangular shape $(1.4 \times 6.3 \mathrm{~m})$. With $8.8 \mathrm{~m}^{2}$ of interior space, Ichon $(1977: 205)$ believed this temazcal would service only two or three people; we believe that figure, however, is an underestimate of seating capacity. This cut stone masonry sweatbath featured a "hearth" against the back wall, though information about its roof was lacking. A large water reservoir was outside the entrance, presumably for rinsing off. A drain provided egress for extra water used to create steam. Because of its location amid structures utilized by elites, Ichon assumed that sweatbath use was restricted to the elite, and he extrapolated that assumption to Classic-period sweatbaths at Piedras Negras, Tikal, and Palenque. 
The other highland sweatbath was excavated by Kidder and Shook (1959) in the department of Quetzaltenango at the Late Classic-Postclassic site of El Paraiso. The structure is circular in plan and is built of naturally shaped flat-fracturing stone. The constricted entryway was $60 \mathrm{~cm}$ wide, which led to the interior floor made of stone-capped concentric benches. The structure is $5 \mathrm{~m}$ in diameter, thus the walls enclosed about $19 \mathrm{~m}^{2}$. Kidder and Shook (1959:73) noted only the outermost bench was large enough for sitting, so when the smaller circles and the firebox in the center are deleted, some $10-12 \mathrm{~m}^{2}$ of space remained for the occupants. The firebox was built of fragmentary manos and metates. The excess water poured out the entryway. They stated the structure probably was capped by an earthen roof supported by wooden poles, and was not a thatch roof. We believe those are not mutually exclusive, and we suggest an earthen roof may well have been protected by a thatch roof above it. If the ceiling above the chamber was earthen, the shape of it would be crucial to know, but Kidder and Shook (1959:73) state "whether the top of the roof was conical or flat is unknown."

The shape of the ceiling in a sweatbath is an essential element in exploring acoustic properties of the structure. Corbel-vaulted ceilings built of cut limestone blocks presumably would have had fundamentally different acoustic properties than the domed sweatbath at Cerén, but they have yet to be studied, in originals or replicas, limiting comparative studies.

Fortunately, there are Late Classic sweatbath chambers in the Zoque area of western Chiapas for which roof shape and composition are known (Domenici et al. 2019). The structures are two stories tall, with the firebox and seated area below. A beam-and-earthen ceiling separated the two stories, thus creating a flat floor for the second story. That ceiling, with the wooden beams and perpendicular wooden support members exposed, would have been highly absorptive of sounds generated within the chamber.

These large, Classic-period sweatbaths contrast with the sweatbaths of more recent centuries following the Spanish Conquest (Shaw 2015:77-86). Families turned to constructing small sweatbaths adjacent to their houses, for their own uses, and building them of the same basic materials. Although the morphology of sweatbaths changed from ancient to historic and modern times, many of the functions have not changed (Shaw 2015:78-80), one of which is personal cleanliness.

\section{Gender and Religious Aspects of Sweatbaths}

The curing of respiratory problems and various illnesses, or restoring the balance of Maya concepts of "hot" and "cold" were common activities in sweatbaths (Groark 1997: 57-58), and those practices were available to people of all genders and ages. Child (2006: 389) notes that when focused upon the hot-cold dichotomy, use of the sweatbath can be therapeutic. The equilibrium of the body can be reinstated by the humid heat eliminating the cold wind that causes sickness. Groark (1997:57-58) mentions some other practices closely associated with sweatbath use, including bloodletting, that appalled the Spanish. During Colonial times, authorities discouraged the construction and use of large sweatbaths, therefore encouraging the more private building and use of small facilities behind family houses. Shaw (2015:77-86) contrasted the large Classic-period structures with the smaller household-associated ones of recent centuries.

The female aspects of sweatbath utilization are well summarized by Houston (1996). Pregnant women use them before giving birth, and often actually give birth in them. Attending frequently is a midwife, usually a woman of postmenopausal status, who helps with foods, drinks, herbal preparations, and ceremonies. Even more intensive medicinal use occurs after the birth, for healing, and protecting the community from possible harm. The umbilical cord and afterbirth are often buried under the sweatbath, and continue to be accessible supernaturally. The buried cord and afterbirth provide a strong connection to home and a sense of place, for the person born there. Sweatbath use ameliorates the pernicious influences that could otherwise occur from the woman and the infant to the community, and vice versa.

Child (2006:345-356) interprets the Piedras Negras sweatbaths as having had powerful religious implications involving the male and female earth deities. The maleness was symbolized by fire, God N, a grandfather creator deity. The femaleness was symbolized by water, and the water nature of birth. The warm moist sweat chamber relates to the fertile womb of Mother Earth, Goddess O, and thus to the locus of all creation. Goddess $\mathrm{O}$ was involved with creation, curing, divination, and childbirth. We suggest that both male and female use of the Cerén sweatbath probably involved transformations, rites of passage, curing, divinations, and other phenomena, so that those crawling out of the narrow passageway to the outer world are undergoing a rebirth. Miller (2013) elaborates on the liminal nature of the Maya sweatbath, with particular focus on the three sweatbaths at Yaxchilan. She agrees with Child that the Maya conceived them to be wombs of Mother Earth. They functioned as entities linking water, the landscape, and the celestial domain. They housed rituals of transformation, healing, purification, relating them to conception, creation, and the womb. She emphasizes the natural, social, and supernatural landscapes as context. All three structures were roofed by corbel-vaulted cutstone masonry with as yet unknown acoustic properties.

McCafferty and McCafferty (2008) explored the Mesoamerican metaphorical relationships among caves, sweatbaths, and the earth mother. The earth, and particularly the earthly waters, were believed to be female. Caves and sweatbaths were portals into the vagina and womb of the earth mother. Therefore entering the sweatbath was returning to the womb of the earth mother, and exiting was to be reborn, transformed, purified, and renewed.

Sandstrom (2005:48, 56) notes how often Mesoamerican peoples employed sweatbaths as metaphors and analogs for caves, with all their potential positive and negative effects. Moyes (2019) argues that cave rituals can tame the potentially chaotic and dangerous forces of nature outside of settlements and that can be extrapolated to the sweatbaths constructed in those settlements. Child (2006:378) also notes the relationships between sweatbaths and caves which are portals to the underworld. Both sweatbaths and caves are special loci that facilitate access to gods and spirits, to the supernatural domain.

The publication by Child (2007) explores the ideological aspects of ritual practice in the sweatbaths of Piedras Negras and Palenque. He states they express monumentality, in contrast to what we see at Cerén's facility expressing more egalitarian functionality. He identifies two kinds of rituals in the sweatbaths which have strong gender implications. The first, of course, is female oriented in pregnancy and birthing, with rituals to restore equilibrium. Water is emphasized, poured over the firebox, and a stream of water flowing out of the exiting tunnel. The analogs with the birthing process are obvious. The other kind of ritual involves both males and females, of all ages, and focus on transformations. These rites change people into a different stage of life, a different age-related 


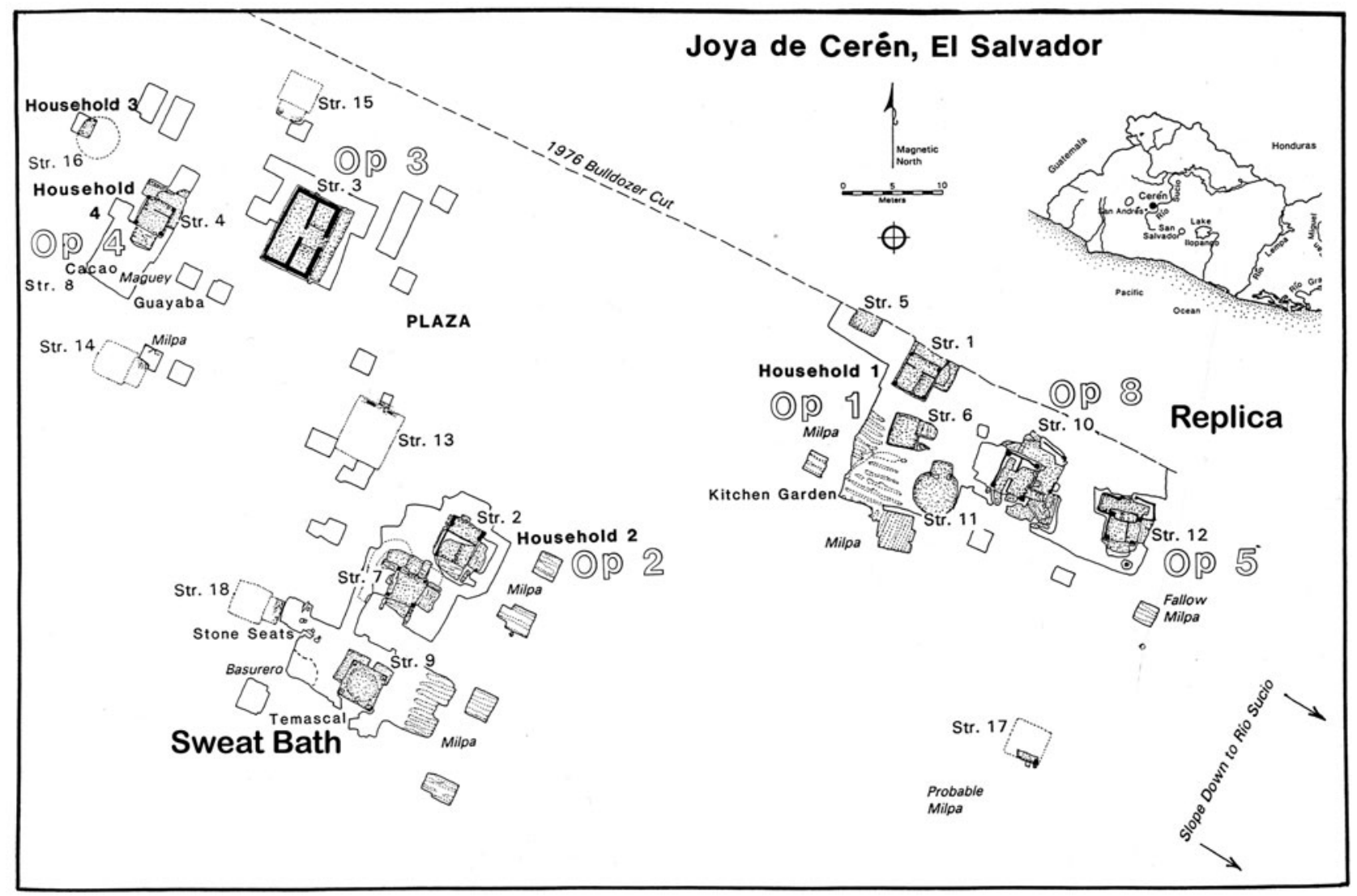

Figure 1. Map of the Cerén site. Structure 9 is the temazcal. The replica was built at the eastern end of the site, where visitors can enter it and experience the acoustic effects on their voices. Map by Sheets.

position, or even a rebirth into a new life. The close association of sweatbaths with ballcourts in the Zoque area (Dominici et al. 2019) may indicate male roles were prominent in both. The rites at the big cities for royals and elites would have been very different from those at the Cerén village, and perhaps even more so at the rural sweatbath that Webster (2018) excavated.

Most Classic-period Maya sweatbaths shared common features including seating for many people within the $10-12 \mathrm{~m}^{2}$ of internal space, fireboxes, narrow entryways, means to release smoke, and solid construction of ceilings and walls to maintain heat and humidity. They varied in construction materials, shapes of ceilings, and their acoustic properties. The literature on gender issues emphasizes female utilization focusing on pregnancy, childbirth, and restoration of equilibrium. Male uses of sweatbaths have received less attention, but the temazcal in the small village of Cerén may provide a window on male use, based on archaeoacoustics research results.

\section{THE ANCIENT CERÉN VILLAGE}

How is it that the Cerén temazcal was found largely intact? The answer to this question lies in the extraordinary preservation of the Cerén site. What is now El Salvador was densely populated in the Early Classic period. The immense eruption of Ilopango volcano (Dull et al. 2001, 2010) toward the end of that period changed the environment from a lush tropical one to a white desert overnight. The eruption evidently occurred late in A.D. 539 (Dull et al. 2019), and essentially depopulated the entire region. A few decades of weathering, plant succession, and faunal recolonization were necessary before people moved in and reoccupied the area. As a part of that reoccupation (Sheets 2002), a few Maya families established a small village on the left bank of the Rio Sucio, in the Zapotitán valley (Figure 1). We estimate the village was occupied for a few generations, from only the A.D. 590 s to 660 s, when it was buried by an eruption from nearby Loma Caldera. Each family used bajareque earthen architecture (reinforced wattle-and-daub), with grass-thatch roofs, to construct at least three structures: a domicile as their principal building, a storehouse, and a kitchen (Sheets 2006). Inhabitants also constructed special buildings, religious and civic, which sported thatch roofs. The underside of the thatch roofs would have been highly absorptive of sounds generated in those structures. The exception is the temazcal, which had an earthen dome below its protective thatch roof. Surrounding each household was an intensive cultivation of seed crops of maize, beans, and squash. Residents cultivated special crops in their kitchen gardens. Manioc was grown in extensive monocultural plots south of the village, from which many tons of the tubers had been harvested just prior to the burial of the village (Dixon 2013; Sheets 2006).

Although the sample is small, each household contributed something as a service to the community. Household 1 maintained the functioning of two religious structures (Beaudry-Corbett et al. 2002). One was Structure 10, the multi-roomed building used for community celebrations and feasting. The commemoration of the harvest was in process when the Loma Caldera eruption occurred. The other is Structure 12, where the diviner/shaman practiced, but she did not live there (Sheets 2006). Her gender was revealed 
by the female-associated artifacts of spindle whorls and foodgrinding implements left in exchange for the services rendered. It is possible that Household 4 was responsible for the maintenance of the public building, Structure 3. Members of Household 4 cultivated specialty crops in abundance sufficient to supply the village with their needs (Sheets 2006). They grew some 70 agave plants for fiber for twine and rope, abundant chili, guayaba fruit, and cane for vertical reinforcements of the bajareque architecture. It is the sweatbath and its acoustic properties that provided a service relationship to the community by Household 2 residents that is the focus of this article. They maintained a community temazcal for use beyond their own household needs.

\section{Household 2}

Information about Household 2 excavations at Cerén provide insights about the role of the sweatbath in this community. Brian McKee was in charge of the 1989-1996 excavations of Household 2 (McKee 2002a) during which time he and his crew encountered a domicile (Structure 2), a storehouse (Structure 7), a temazcal (Structure 9), a midden, and agricultural fields surrounding the structures. This household shared many characteristics with others in the village, by using the earthquake-resistant bajareque architecture that was oriented 30 degrees east of north, building functionally specific structures, and being largely self-supporting in food production, though the kitchen has yet to be discovered. Each household produced a commodity in excess of what they needed for their own members' consumption, for exchange within and outside the community. In the case of Household 2, residents specialized in part-time craft production of painted gourds (Sheets 2006). All the buildings had grass-thatch hip roofs, meaning they were pitched in four directions. The roofs extended about 1.5 meters beyond the walls of the domicile and the storehouse, more than doubling the area covered, therefore providing considerable shaded and dry area outside the buildings' walls. The abundance of artifacts was striking, with the household on track to have an inventory of about 70 complete ceramic vessels, if the kitchen can be found and excavated (Sheets 2006). Obsidian knives were abundant, and stored in the thatch of the roofs in predictable locations, as a means of child-proofing their residences and protecting the cutlery.

The storehouse is the closest household building to the temazcal (McKee 2002a), and in addition to proximity, at six m, it revealed some stored items of significance to keep the sweatbath functioning. On its shelves were found an unusual number of ollas, water carrying and storage vessels, for pouring water over the firebox to make steam, and likely for rinsing off after exiting the building. It also contained pine kindling/firewood, and was the only storehouse with this resource. Items common to the other storehouses (ceramic vessels of all sizes and functions, obsidian knives, grinding tools, gourds storing wood ash, a jade celt, iron and mercury-based pigments, and other items) were likewise found in the storehouse associated with Household 2 (McKee 2002a). As with the other households, Household 2 was awash with material culture, in contrast to the temazcal to its south, which held not a single artifact.

\section{THE ANCIENT CERÉN TEMAZCAL: CONSTRUCTION, FORM, BURIAL, AND EXCAVATION}

During McKee's 1990 (2002b) excavations south of Structure 7 (McKee), he and his crew encountered the most unusual building

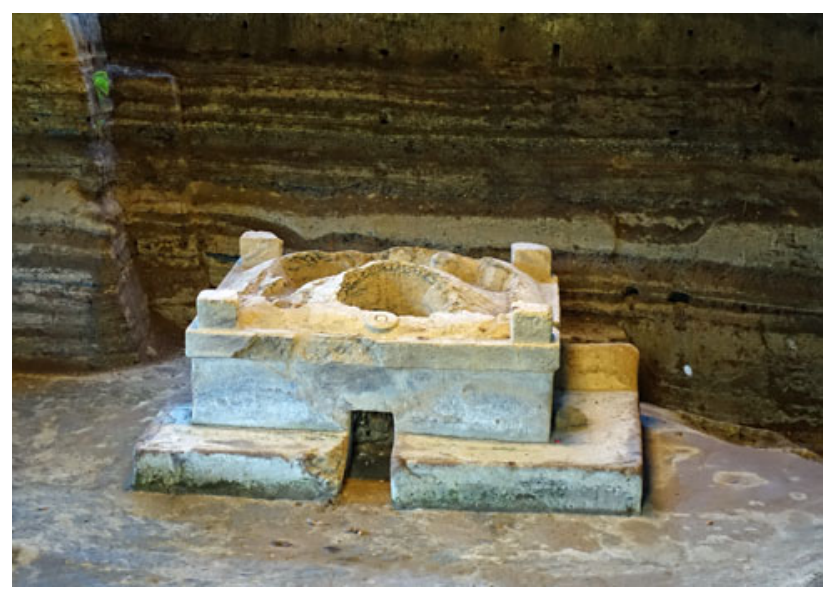

Figure 2. The Temazcal at Cerén. The earthen architecture with the dome was protected by a thatch roof. The stubby earthen columns at the corners supported the horizontal beams that formed the basis of the thatch protective roof. Two lava bombs penetrated the roof and dome, damaging them, but allowing tephra to support other portions of the dome. The bench surrounding the structure extends inside to form the interior floor. The front wall, above the bench and entrance, is $3.75 \mathrm{~m}$ wide, and $1.18 \mathrm{~m}$ high (including it extending up, inside of the cornice). Some of the volcanic ash layers that buried the building are seen behind it. Photograph by Sheets.

of all those excavated to date at Cerén (Figure 1). It is Structure 9, a temazcal (Figure 2). It is so different from the household structures, from the religious buildings, and from the public building, yet it is so sophisticated, that there must have been a long tradition of constructing this type of building. Furthermore, it suggests to us a great intentionality in its constructed morphology and internal features, which we believe probably included its acoustic effects on sounds, similar to those generated inside its replica. It even had a double roof, consisting of the dome of earthen architecture, protected by a thatch roof above it. Because of this discovery, we suggest the sweatbath at El Paraiso in Guatemala (Kidder and Shook 1959) also had both an earthen and a protective thatch roof.

The first component of the Loma Caldera eruption was a lateral blast caused by a steam explosion $600 \mathrm{~m}$ to the north. As the magma contacted water in the Rio Sucio, it exploded, and deposited a pasty wet hot tephra all over the site, and coated the temazcal (Sheets 2006). That episode was followed by a dry phase, where volcanic ash, cinders, and lava bombs were blasted into the air and fell across the village. Two lava bombs penetrated the sweatbath dome (Figure 2) and almost destroyed it. The holes, however, fortunately allowed cinders and volcanic ash to enter the dome, and pack into the areas below the still-intact components of the dome. Had the lava bombs not created those holes, the weight of tons of volcanic ash above an empty space would have totally collapsed that dome. That scenario would have made an accurate reconstruction impossible. Fortunately, sufficient elements of the dome were preserved to allow a precise dome reconstruction in the replica.

\section{Construction of the Ancient Temazcal}

The very first step in the initial construction of the temazcal, toward the end of the sixth century, was to create a low mound of clay, higher in the center, and broader than the final building, which allowed for rainwater running off the roof to drain away from the building. It also created a slight slope from the firebox downward 
to the entrance and beyond, to allow water poured on the firebox to exit the building. The second stage of construction was to build a square, solid adobe platform, which formed the seating floor inside the building and the external bench surrounding half of the exterior. That surface is penetrated on the north side by a narrow entryway that can be negotiated only on hands and knees. It ends at the domed firebox.

The next step in construction was to create the solid, rammed-earth walls, and finish their tops with a cornice running around all four sides. Short earthen columns were added at each corner to support horizontal beams, with poles running upward to support the grass-thatch of the roof. The thatch roof extended well beyond the building walls, and covered the bench on the front and sides. The driplines from water running off the thatch roof were preserved, allowing for precise measurements of the size of the protective roof.

Prior to constructing that protective roof, the dome was built. The first stage was to implant canes in all four wall tops to meet in the center, each bent enough to create a domelike shape. Before implanting, the canes must have been curved to the desired shape of the planned dome. Perhaps they were all moistened and sustained over a form that had the curvature of the desired dome, and dried to retain that curvature. The next step was to anchor each cane base into the top of the wall, then connect them in the center, and add the cross-reinforcements which were fashioned from either vines or agave twine. Then the canes were mudded on top and on the underside. After mudding, the result was a smooth and uniform dome. The challenges of dome creation are considerably beyond that of a wattle-and-daub wall. The planning, execution, and final result may well have been intentional for its notable acoustic effects.

During dome construction, a perforation was made above the entrance, and encircled with a rim that appeared somewhat like a donut. It had an informal clay plug in it when excavated, but we believe that plug would be removed after the fire had fully heated the firebox. It would have been smoky inside, but opening that vent would allow smoke to escape. Means of ventilating other sweatbaths are mentioned by Domenici et al. (2019) and Shaw (2015). Then water poured on the firebox created stream, and people could enter and utilize the temazcal. It is likely a temporary door was placed in the entryway, but evidence for this feature is lacking.

The interior seating area was covered with lajas, i.e., flat-fracturing exfoliated andesite slabs. They were covered with a $1-2 \mathrm{~cm}$ thin layer of Ilopango Tierra Blanca Joven (TBJ) volcanic ash. It is possible the TBJ tephra was replaced after each use, or only the last use. Its presence might have been there for symbolic reasons, for ceremonies recalling that immense eruption/disaster. A domed firebox was constructed in the center, with its base at the same level as the bottom of the entryway tunnel. It was made of lava stones set in clay mortar, which fired hard with use. The location of this firebox differs from most Maya lowland fireboxes that were placed against the back wall of their interiors (Houston 1996; Shaw 2015).

Child (2006, 2007) identified two kinds of rituals that evidently took place in the monumental sweatbaths of Piedras Negras and Palenque. The ones involving pregnancy, birthing, and restoring equilibrium obviously are female-associated. The rites of transformation into a different stage in life, could be focused on either gender or people of any age. Although the scale of actual ceremonies would have been more modest at Cerén, it is almost certain that both kinds were practiced in its temazcal. The latter may have taken advantage of the acoustics emphasizing adult male voices. Shaw (2015:80) notes that licit and illicit sexual activities took place in the monumental sweatbaths, and those behaviors probably pertained to the Cerén structure as well.

\section{THE REPLICA AND INITIAL ACOUSTIC STUDY}

The senior author of this article began suggesting the construction of a replica, or replicas, of the ancient Cerén buildings to various Salvadoran government officials in the early 1990s. So many visitors stated that they were fascinated by the ancient structures that they wanted to get closer to them. Of course, they cannot be allowed to touch the originals so, for many years, the building of at least one replica was agreed upon. No action was taken, however, for two decades for lack of funds. It was not until 2012 when the Corporacion Salvadoreño de Turismo offered to fund the project that plans for construction materialized. Visitors, archaeologists, and government officials all agreed that the temazcal was the building to replicate. Modulare Arquitectos, a well-respected Salvadoran architectural firm, was awarded the project in June of 2012. The architect José Roberto Ortiz Novoa, the leading architect of the firm, took responsibility for the project. The engineer Hector Cardoza was in charge of the construction. Ortiz submitted the proposal to the Secretaria de Cultura a la Presidencia (Secultura) in July that consisted of text, plans, sections, and elevations of the replica, and a schedule of work. Secultura examined those materials, checked them for accuracy to the original building, and gave the approval to proceed in August. Actual construction of the replica began in October and was finished November 3, 2012.

The replica (Figure 3) precisely duplicates the original temazcal in exterior and interior morphology, features, and measurements, reconstructing it to its condition prior to the Loma Caldera eruption. The architectural firm used McKee's (2002b) measurements, plans, and sections and did their own measurements from the original to make the replica accurate. This acoustics project began shortly after its construction, when the senior author of this article entered the replica, and noted how fundamentally it changed his voice. He noted how much lower in pitch his voice sounded while inside, compared to speaking outside.

To explore the nature of the acoustic effects, in 2017 he made a sound recording of his voice outside the replica, continuing to inside, and then back outside, for comparative purposes, using a Sony Panasonic DSC RX100M4. That recording was taken to Thomason of the Physics Department of the University of Colorado. Results of that study are published in Sheets and Thomason (2021). Thomason noted the unique acoustics inside the structure due to its size, shape (especially because of the domed ceiling), and the hard reflective surfaces. Thomason was the first to do an analysis of the decay of speech inside the temazcal and identified the frequencies most prominent in that decay as related to the natural resonances of the enclosed volume. Especially, he identified the strengths and interaction of the two lowest resonances, reverberating and slowly decaying modes of the spoken word. His research was able to attribute conclusively the resonances to the geometry and materials of the interior of the temazcal by comparing recordings made inside the structure with those made immediately outside, using the same talker.

Following the groundbreaking research by Thomason, Sheets turned to Robert Mahoney, an acoustician. Mahoney loaned Sheets a more sophisticated, professional sound recording instrument than what was used for the initial experiment. A Tascam 


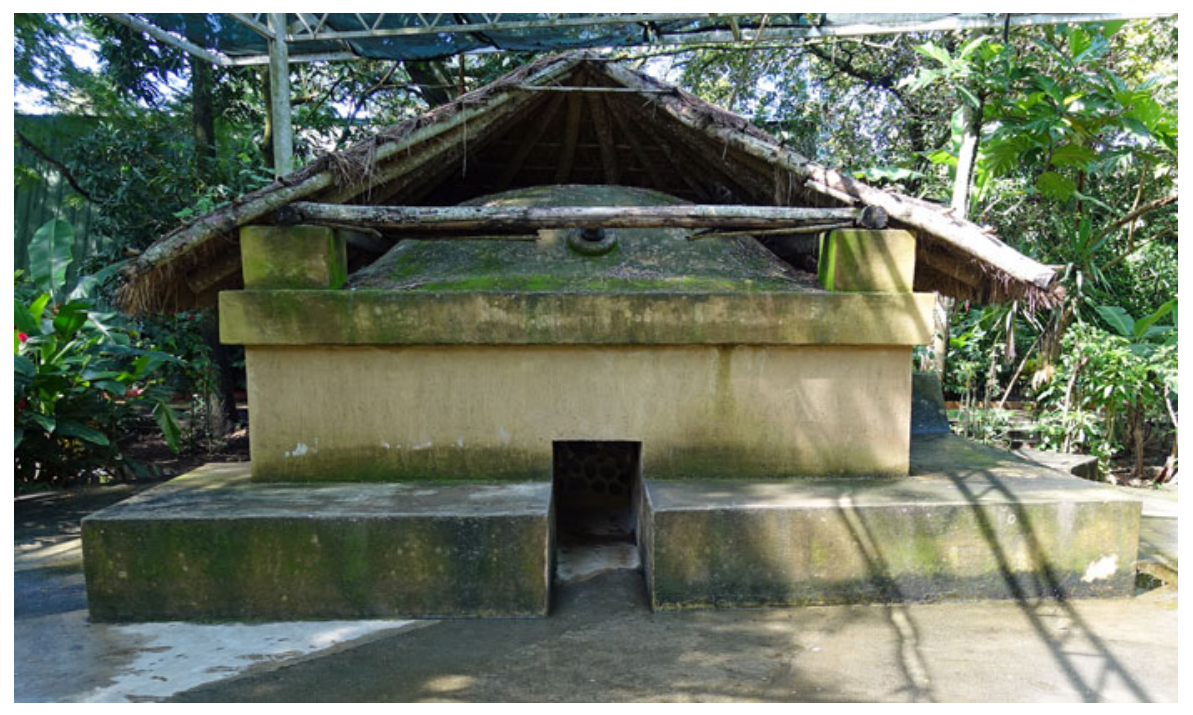

Figure 3. The Temazcal replica. It is located in the public access area of the archaeological park so people can enter it and experience the acoustic phenomena. The interior floor is the extension of the exterior bench. The front wall, above the bench and entrance, is $3.75 \mathrm{~m}$ wide and $1.18 \mathrm{~m}$ high (including it extending up, inside of the $28 \mathrm{~cm}$ high cornice). Photograph by Sheets.

DR-40 Linear Pulse Code Modulation recorder was employed to increase the resolution. The results of Mahoney's research are presented in the following section.

\section{THE SECOND RECORDING AND ACOUSTICAL ANALYSIS}

\section{Background and Context}

An English acoustician, Bagenal, divided auditoria into two groups: those in enclosed spaces, such as caves and rooms, versus those in the open air (Forsyth 1985). Enclosed spaces evolved into venues for music, such as concert halls, while open-air spaces, more favorable to the spoken word, were the forerunners of the theater. Fully contained artificial enclosures are particularly interesting; acoustic effects are more pronounced because sound energy generated in such spaces is not quickly lost to the open air and even fairly weak sound sources can excite a perceptible acoustical response.

\section{Summary of Architectural and Subjective Acoustical Aspects}

The temazcal at Cerén is unique for three reasons: the most significant attribute is the domed ceiling, the only such construction so far found in the Maya area; the interior surfaces are all highly reflective acoustically with only very small openings to the outside; and the floor plan is square, as both length and width are identical. What makes the acoustics of the temazcal, a small and tightly enclosed space, so intriguing? Sounds originating within the space are altered and grow stronger while the sound source is active; once the source stops, the sounds decay in remarkable ways. Subjectively, sounds seem to linger for an unusually long time while their timbres are increasingly dominated by low tones as they fade away. There are strange rapid variations in the strength of some components of the decaying sound and, depending upon location, the sound source seems larger than life as if it were amplified by the temazcal.

\section{Relevant Acoustical Fundamentals}

Interior acoustics deals with the interaction of the geometry of the enclosure with sounds of various wavelengths, both of which are described in terms of dimensions (feet or meters). On the other hand, the ear does not respond to wavelengths, but responds to the strength and repetition rate of variations in air pressure, measured in decibels $(\mathrm{dB})$ and hertz (Hz, or cycles per second), respectively. Fortunately, we can describe sounds by either wavelength or frequency (used interchangeably here), given that they are uniquely related by the formula, where $\mathrm{c}$ is the speed of sound in a medium, $\mathrm{f}$ is frequency in hertz and $\lambda$ is wavelength in units of distance:

$$
\mathrm{c}=\mathrm{f} \times \lambda
$$

\section{Interior Versus Exterior Sound}

The difference between interior and exterior spaces is entirely a matter of reflections. In the open air-especially where there are few reflective surfaces nearby and those that are present are acoustically absorbent to a high degree — sounds are almost completely devoid of reflections. Sound is heard once and only once by a listener before the energy is completely carried away and contributes nothing further to the overall impression. The acoustics of enclosed spaces, on the other hand, are the result of reflections that in turn are determined by the extent of the enclosed air volume, the geometry of the room boundaries, and the degree to which the energy of sound waves incident on these boundaries is absorbed or reflected.

Where the cubic volume of a room is large and the geometry is not highly irregular, the room boundaries are inherently far apart. Consequently, sound waves radiating from a source encounter the room boundaries less often than is the case where the cubic volume is small and boundaries are much closer together. Regardless of the volume of a space, when a sound wave encounters a room boundary, some of its energy is lost. How much depends on the absorptive properties of the boundary (as well as the wavelength of the sound with respect to the room dimensions, dealt with below under room modes). Materials with a high degree of absorption are generally porous or highly flexible, like thatch, vegetation, pine needles on a 

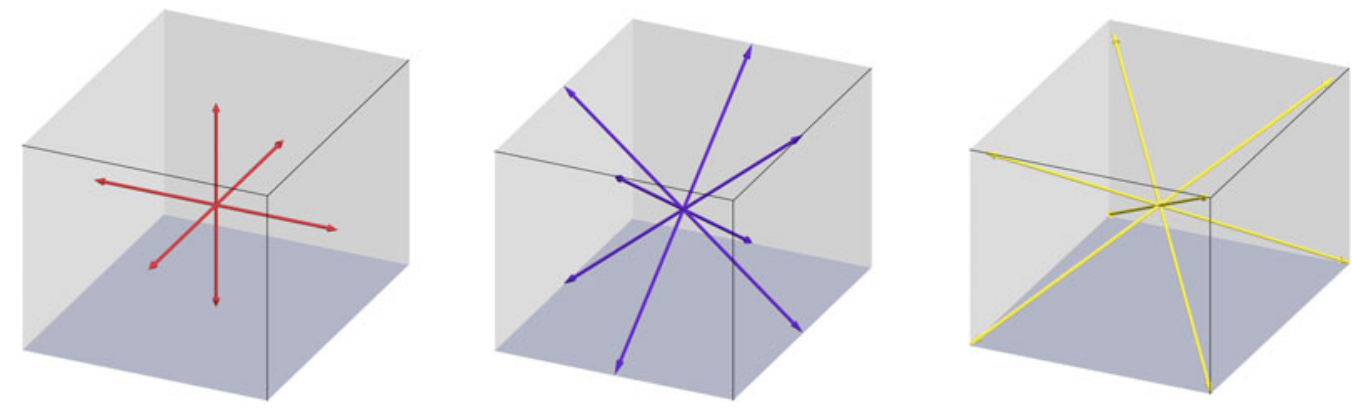

Figure 4. Room modes of a parallelepiped: planar, dihedral and trihedral. Image by Sheets.

forest floor, sand, or loose soil. Highly reflective materials are dense and heavy and without fine surface porosity, for example, pavers of densely grained stone or plastered walls. If room boundaries are highly absorptive, then the interior geometry and spatial arrangement of the surfaces are less significant factors in the overall acoustics. When sound energy is absorbed at each reflection, the strength of a continuous sound cannot increase much at all. Once the sound stops, it fades away very quickly. Indeed, in small spaces where sound waves encounter many highly absorptive boundaries in very quick succession, the acoustics can closely approach those of open-air conditions. Where room boundaries are highly reflective not only do continuous sounds build up strength over time and persist after the sound source stops, the interior geometry can add some additional extraordinary effects. All of these conditions and properties are what make the temazcal so intriguing.

\section{Room Modes, Room Resonances, Favored Frequencies, and Their Implications}

Every closed or partially enclosed space with even slightly reflective surfaces will exhibit "room modes," "room resonances," or more colloquially "favored frequencies." These attributes are the specific frequencies at which standing waves arise more or less quickly when excited by sound sources that contain energy at those favored frequencies. So long as the sound source is continuous, these standing waves will increase in strength over time (up to a limit), which is an increase we perceive as ever greater loudness. When the sound source stops, the energy of these frequencies will be absorbed by the boundaries much more slowly than the energy of nonfavored frequencies. This effect causes the favored tones to linger on. In the case of the temazcal, this "lingering" is quite pronounced. This aspect is why the timbre of sounds inside the temazcal seem to evolve and grow darker over time.

For even slightly irregular spaces, the calculation of these resonances is challenging and not at all intuitive, either mathematically or visually. For simple geometries, however, the math is much simplified and visualization is not difficult. A simple geometry similar to that of the temazcal-at least in terms of its geometry in -is a parallelepiped. This figure is a six-sided space with a rectangular floor plan and an identical ceiling plan bounded by perpendicular walls on all four sides. The room boundaries of a parallelepiped (Figure 4) are such that waves reflected from them are sent back in a direction that is exactly opposite of that from which they arrived which results in the creation of standing waves, even for sounds of very short duration.

Planar parallel surfaces, dihedral edges (e.g., floor/wall and wall/ceiling intersections at right angles) and trihedral corners where surfaces are acoustically reflective are particularly good conditions for standing waves. A good visual analogy to the parallel planar surfaces are the "infinite" reflections one can see in barbershop mirrors. The wave reflection that takes place at the intersecting planes of dihedral edges is analogous to a billiards player making a bank shot (Figure 4).

The distances among the room boundaries that fulfill these conditions are very important because sounds whose wavelengths match these dimensions are very strongly sustained and constitute the "room modes" or "room resonances." It is necessary to consider what "matching" the dimensions between reflecting conditions implies. A match occurs for all frequencies whose wavelengths are one-half the dimension, exactly the dimension, 1.5 times the dimension, two times the dimension, and so forth. As noted above, expressed mathematically, if $\mathrm{c}$ is the speed of sound, the relationship between frequency, $f$, and wavelength, $\lambda$, is $f=c / \lambda$. If $D$ is the dimension that gives rise to standing waves and $\mathrm{N}=1,2,3, \ldots$, then the resonant frequencies that exist for that particular set of reflecting surfaces is $\mathrm{f}_{\mathrm{N}}=\mathrm{N} \times(\mathrm{c} / 2 \mathrm{D})$.

$\mathrm{D}$ of course is different for all the various conditions of planar, dihedral, and trihedral conditions, but nevertheless in every case it can be derived from the length, width, and height of the parallelepiped. If the three possibilities for D are instead represented by $p, q, r$, and the integers, $1,2,3 \ldots$ for each mode are given by $1, \mathrm{~m}$, and $\mathrm{n}$, then the general formula for the resonant frequencies of all possible modes is (Long 2006: 295):

$$
\mathrm{f}_{\operatorname{lmn}}=(\mathrm{c} / 2) \times\left[(\mathrm{l} / \mathrm{p})^{2}+(\mathrm{m} / \mathrm{q})^{2}+(\mathrm{n} / \mathrm{r})^{2}\right]^{1 / 2}
$$

The resonant frequencies that result in any one condition form a harmonic series where each is an integral multiple of the lowest fundamental frequency. Whether due to cultural conditioning or some more universal cause, this series is considered inherently musical. It generates the musical intervals we call an octave, then a perfect fifth, a perfect fourth, a major triad, a somewhat flat dominant seventh and then begins a diatonic major scale, a chromatic scale, and then a nearly continuous series of very high overtones.

It should be noted that this harmonic series that creates the resonances will arise for each and every case in which the geometrical and absorptive conditions are met. And if all the relevant dimensions, $\mathrm{p}, \mathrm{q}, \mathrm{r}$, do not have simple relationships to one another (1: $1,1: 2,1: 3, \ldots)$ they will not be harmonically consistent.

It is also worth noting that even if such simple relationships existed, one could not "play along" in tune with these resonances with customary western instruments. Contemporary western instruments are usually tuned to a reference pitch such as $\mathrm{A}=440,441$, or $442 \mathrm{~Hz}$, whereas the overtone series of the space in question may not align with those reference pitches. Moreover, the tones 


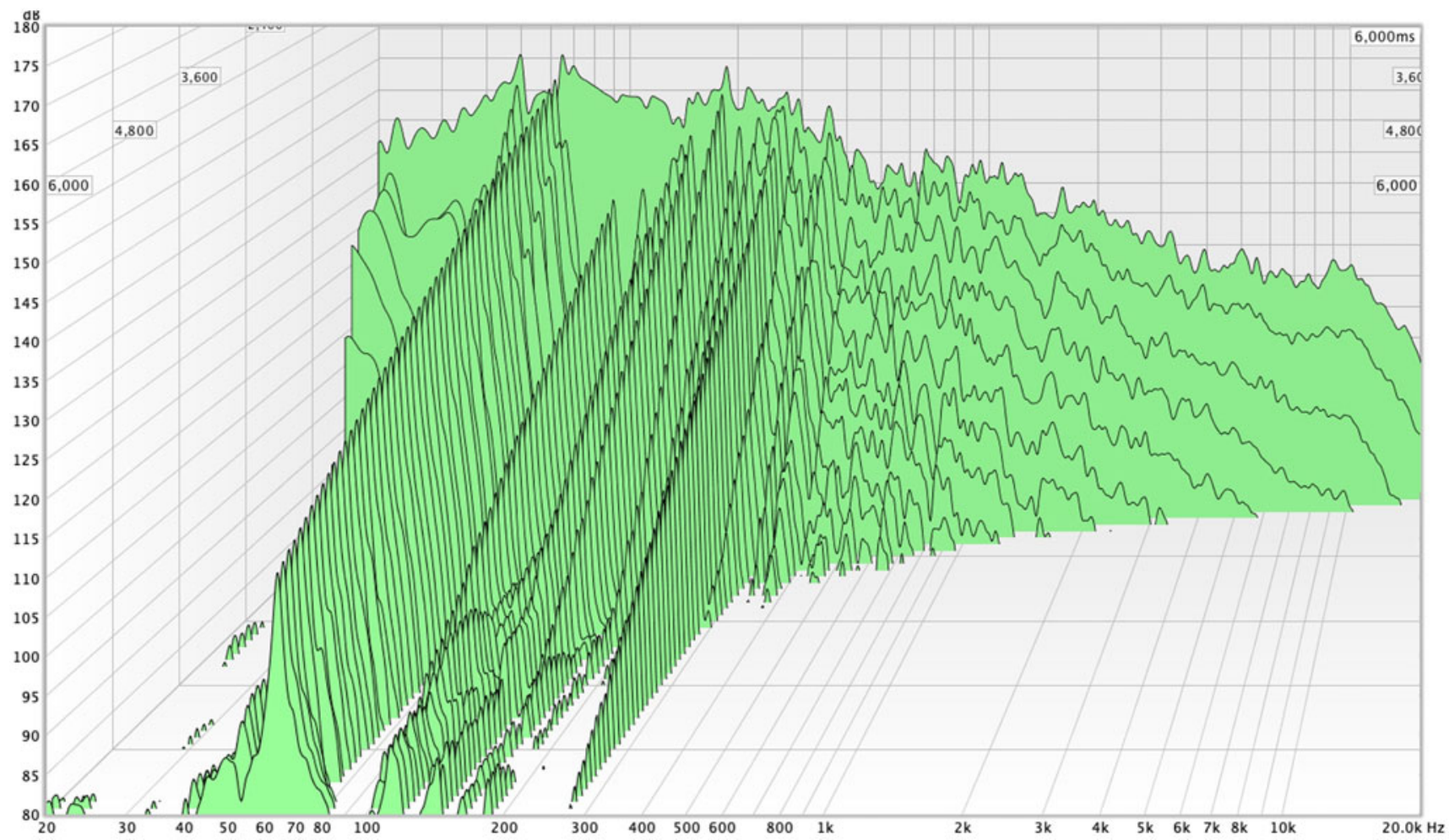

Figure 5. Waterfall display: room response to a balloon burst. The $\mathrm{x}$-axis is frequency and the $y$-axis is relative (not absolute) sound pressure level and the progression of time after the burst proceeds along the diagonal axis from back to front over a six-second interval. The "ridges" in the figure show the preferred frequencies that decay far more slowly than the others. Image created using Room Acoustics Wizard (REW) software (http://www.roomeqwizard.com). Image by Mahoney.

generated through spatial resonances are related by simple ratios of small integers and define what is termed a Pythagorean temperament. On the other hand, the tones produced by western instruments are based on subdivisions of an octave such that the ratio of the frequencies of adjacent subdivisions is always the same. This requirement for constant ratios defines the system of equal temperament. Except in the case of an octave, tones forming harmonic intervals based on these two temperaments will not have identical frequencies.

\section{Audible Consequences of Strong Resonances in an Enclosed Space}

How perceptible all these resonances are depends on a large number of factors. First, the resonant frequencies must be present in the source of the sound-while the potential for room resonances always exists, they will not arise without proper excitation. Second, the audibility of the decaying components depends on their initial strength, which in turn is related to how absorptive the room boundaries are; the more reflective, the more quickly will sustained sounds build up and the more slowly will they decay. Under the best conditions, even if the resonant frequencies are only weakly present in the sound source, they could build up to clearly audible levels over time.

Yet another significant factor is spacing between the various room modes. The effect of widely spaced room modes is easily experienced. If in a small, hard shower stall one sings a glissando (a tone that slowly sweeps over a broad range of tones), you will hear some tones that suddenly leap out very strongly. These are the preferred frequencies. The same exercise in a bare but even moderately large unfurnished room will still excite the room modes, but because it is large, the fundamental frequencies are much lower. The higher resonances that are in the range of human speech are close together and therefore much less remarkable.

A comprehensive measurement of the room modes of the temazcal replica would be a complex procedure involving a great many measurements using controlled positioning of both sound sources and measurement locations. By examining reverberation times at various frequencies, however, we can learn something with a much simpler test that proves to be highly informative. Following standard acoustical measurement techniques (International Standards Organization 2009), a large balloon was burst inside the temazcal and the resulting sound decay was recorded with a digital recorder (Tascam DR-40) for subsequent analysis. The sound recording was analyzed using REW (Room Acoustics Wizard) software to produce a waterfall display of the data (Figure 5) where the frequency resolution is $1 / 24$ octave bands.

While the waterfall analysis does not explicitly yield reverberation times, the level of resolution it provides is such that the strong resonant frequencies are clearly identifiable. In Figure 5 the horizontal axis represents frequency, the vertical axis relative sound pressure level (i.e., signal strength), and the diagonal axis is time elapsed after the initial impulse. Each trace represents conditions as they evolve over small increments of time, in this case 120 milliseconds. The entire time window is six seconds and proceeds back to front in the illustration. Notice the very slowly decaying frequencies that show up as "ridges" in this waterfall. These are the preferred frequencies corresponding to room modes. The most prominent ones are at $64,93,137,152,186$, and $273 \mathrm{~Hz}$. 


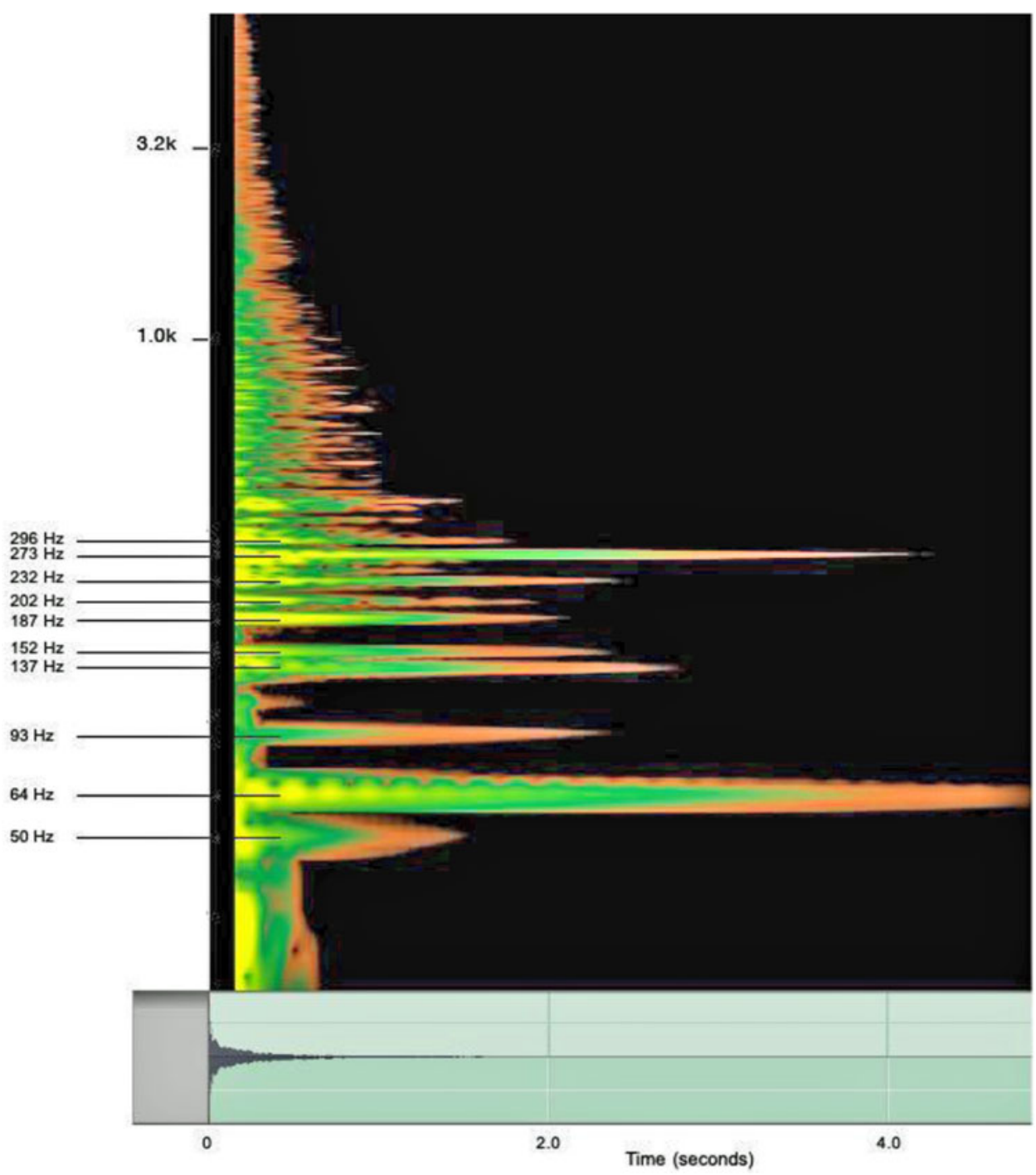

Figure 6. A sonogram of a recording of a balloon burst inside the temazcal and the six seconds thereafter. Note the amplitude modulation of the $64 \mathrm{~Hz}$ resonance first recognized by Thomason. Image created by Mahoney using Amadeus Pro (Acoustical Analysis Software) employed (http://www.HairerSoft.com).

A less quantitative but much more intuitive and readable display of the same information is the sonogram in Figure 6 produced by Amadeus Pro software in which intensity is shown by gradations of color (or grayscale). As in Figure 5 the vertical axis is frequency and the horizontal axis is time. The greatest energy is shown in white. The frequencies listed on the left side of the figure are those for which the rate of sound decay was much greater than at others. These correspond with the "ridges" in the waterfall in Figure 5.

As mentioned above, one of the characteristics of the preferred frequencies is that their energy is sustained for a relatively long time after the sound source stops, so it is reasonable to infer from the sonogram that at least some of the room modes are revealed by this analysis. It may be, however, that not all of them are revealed. If the measurement microphone was at a node of a standing wave it would record very little decay and produce no trace in the sonogram. Likewise, if the balloon burst contained no energy at a particular preferred frequency there would be no decay and no telltale trace.
It is in the low frequency range, however, where the room's modes are most prominent and influential, and that is the frequency range where a large balloon burst has the most energy. Indeed, the apparent mode at $64 \mathrm{~Hz}$, while very prominent in the sonogram, might not have any special significance; instead, it might just indicate the balloon burst was especially powerful at that frequency and the initial energy level was particularly strong and so took longer to decay completely. In fact, the waterfall study shows that both these factors were indeed present. Note too that the balloon burst also excited the room at frequencies typical of children and adult females. No strong resonances, however, were apparent in that frequency range.

The lowest frequency identified in the sonogram, $50 \mathrm{~Hz}$, is below what even a basso profundo singer can produce. The next higher frequency, $64 \mathrm{~Hz}$ is two octaves below middle $\mathrm{C}$ and is within the range of such a voice. But $93 \mathrm{~Hz}$ is approximately as low as a conventional bass can sing, while all the higher frequencies up to $232 \mathrm{~Hz}$ still do not go higher than what we know as middle $\mathrm{C}$. At even higher frequencies, the resonances 


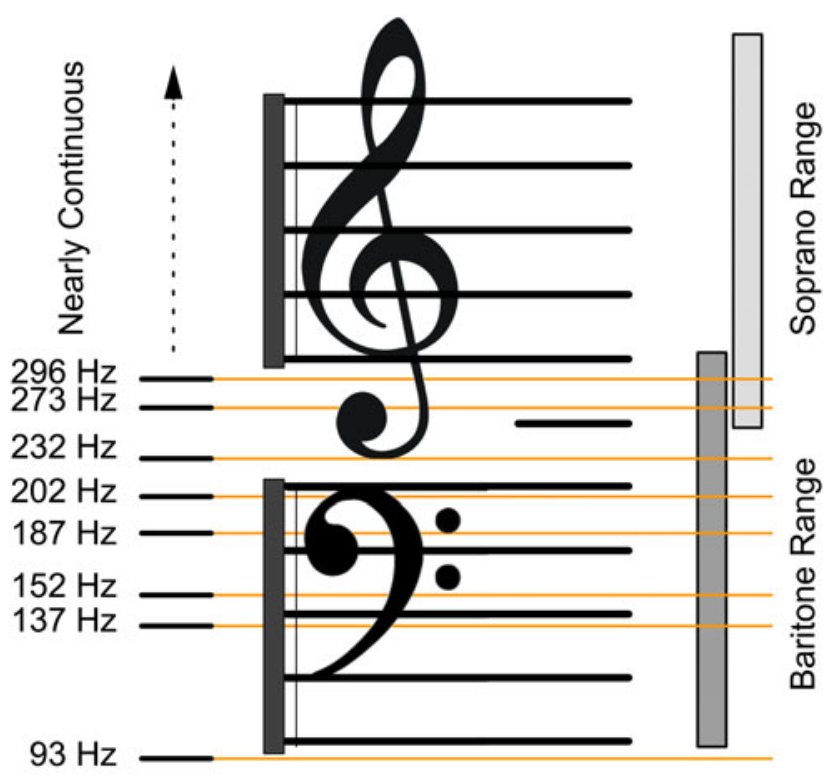

$64 \mathrm{~Hz}$

\section{$50 \mathrm{~Hz}$}

Figure 7. The strong resonances on the left hand side identified are shown in relation to the approximate range of adult male and adult female voices and in relation to contemporary musical notation. Image by Sheets.

are far less prominent because they are weaker, closer together and even start to overlap. Figure 7 presents a graphical representation of these relationships.

This may be significant, because it suggests that the peculiarities of the temazcal's acoustics are far more likely to be excited by adult men's voices than those of adult women or children. Indeed, in such an acoustical environment someone chanting a constant tone at a resonant frequency might be able to pause briefly to take in a new breath without the interruption being heard by others in the space - the appearance of a continuous drone would be maintained.

\section{The Ceiling, Ray Tracing, and Apparent Amplification}

The acoustical effects of a concave ceiling are significantly more complex to analyze in terms of room modes than a planar horizontal ceiling. Additionally, the floor of the structure is also far from a simple plane because of the firebox in the center. While modal analysis is significantly affected by the number and disposition of people inside the temazcal, the sounds reflected from the ceiling would likely be largely the same regardless of occupancy. To study the focusing effect of the concave ceiling, we move away from treating sound as a wave phenomenon and instead look to geometrical acoustics or ray tracing.

Raytracing is an analytical tool that assumes sound waves act like particles and respect all the rules of optical reflection, specifically that reflections are specular (i.e., that the angle of incidence equals the angle of reflection). While not strictly true for all frequencies, this simple tool shows how for positions that might reasonably be taken by a person speaking, singing, or playing an instrument, and by a person listening, the dome focuses a great deal of energy on the listener (Figure 8). Importantly, while this figure is a two-dimensional depiction of the interior of the temazcal, in fact the focusing is more intense because it happens in three dimensions.

In the strictest sense, amplified sound is sound that is stronger because some external energy source has increased the strength of the original sound. In the temazcal there are no external energy sources. In a colloquial sense though, amplified sound may mean sound that is stronger than would normally be expected regardless of the mechanism by which the sound was strengthened. Therefore, for occupants in the temazcal sounds would not only be altered in timbre but also greatly increased in strength.

\section{Timbre}

Except for electronic sources of sound, there are very few sources of pure, single frequency tones. Tuning forks and transverse flutes

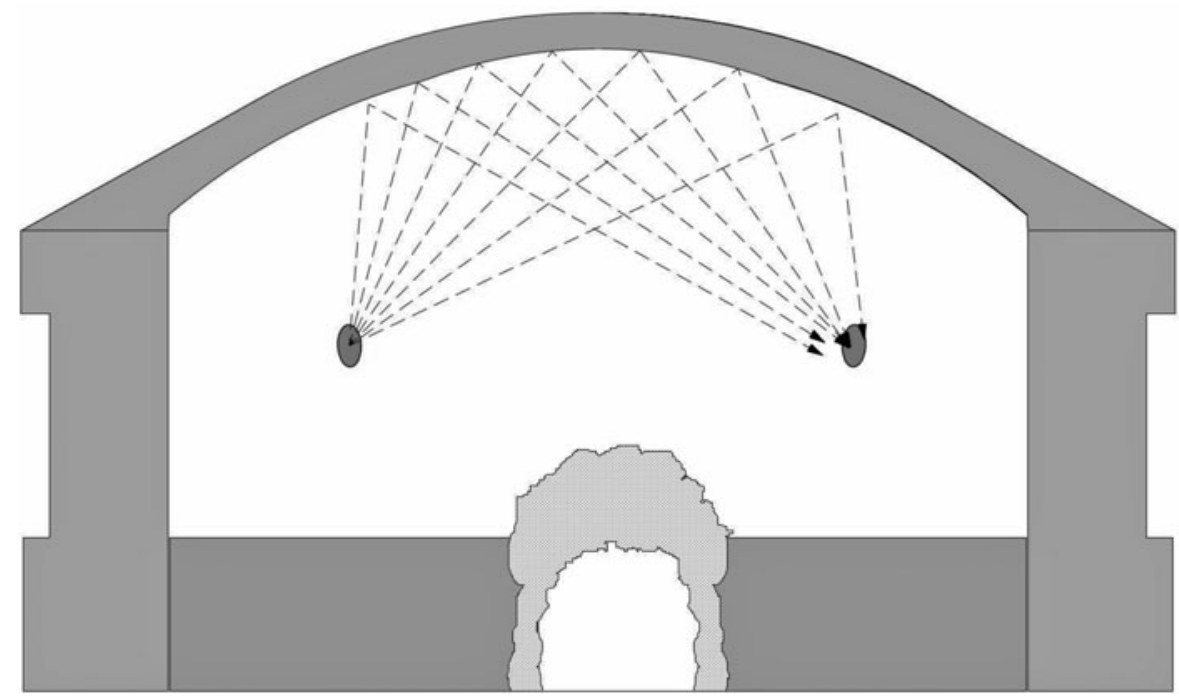

Figure 8. Section view of the temazcal: ray tracing study illustrating effects of concave underside of the dome. Image by Mahoney. 
played in the upper register are some of the few that do exist. Indeed, nearly every sound we hear is made up of many frequencies, each of different strength. A precise description of both frequency and amplitude (strength) is called a "spectral energy distribution" and the perception of that distribution gives rise to the sense of "color" or timbre of the sound.

The human ability to discern and interpret timbres even as they change very rapidly over time is a potent tool (Handel 1995). Consider an urban streetscape. You are waiting at a bus stop, there is a lot of traffic and someone is playing music. A friend approaches you unseen and greets you. In the space of milliseconds and without any warning, you discern the human voice amidst all the noise, recognize it as a voice you know and can identify vowels and consonants to make sense of the greeting-all on the basis of timbre.

The overall effect of the strong room modes in the temazcal is to make enormous changes in the timbre of sounds (music or voices) heard inside the space as compared to what is heard outside, in other settings. Remarkably, based on recordings inside the temazcal, it is apparent that voices are radically changed in timbre but still individually identifiable. This judgement is necessarily subjective; timbre is one acoustical attribute that has resolutely resisted objective quantification. Tristimulus diagrams have been proposed, but even these, at root, are based on subjective judgements. (Fletcher and Rossing 1998:575).

It is interesting to speculate how listeners inside the temazcal may have enhanced their belief that perhaps a shaman was serving as a conduit for spiritual forces because of the acoustical changes in a medium's normal voice. Another observation is that having a plastered ceiling exposed to interior sound rather than a thatched underside of a roof would alone create unusual acoustics because of the vastly different absorptive/reflective properties of the two materials.

\section{Summary}

In terms of acoustical performance, the relevant features of the temazcal are its very small scale, its square plan and the consequently overlapping resonances, and the reflective and focusing ceiling geometries. It is quite likely that for people who lived largely out-of-doors or in thatch-roofed household buildings, the acoustics of the tightly enclosed temazcal would have provided an extraordinary experience that was remarkably different from their everyday experiences inside the other buildings in the village, or outside.

\section{Suggestions for Future Research}

Many aspects of future research could be investigated, both in the Cerén replica, and in sweatbaths elsewhere. For instance, at Cerén, the reflectivity of the wattle-and-daub surfaces of the ancient temazcal could be compared to the reflectivity of the replica. The number of people inside may affect the acoustics. Spoken versus singing voices, chanting, and musical instruments such as Classic-period "ocarinas" (fired clay flutes) and drums should be employed and studied. Because of the gender issues, women's voices should be examined. More sophisticated recordings could be done, with multiple sound sources, and multiple recording microphones, in a variety of locations, to explore the rich variety of room modes.

Other sweatbaths in the Maya area, and others in Mesoamerica, which are complete with roofs, could be investigated archaeoacoustically. The reflectivity of Maya limestone cut stone masonry construction, with corbel-vaulted ceilings, should be fairly high, especially if they were/are plastered. Because they have never been studied acoustically, their properties are completely unknown. Once basic studies, such as that reported here, are completed, the other suggestions for more elaborate investigations, made in the above paragraph, could be employed.

\section{SUMMARY AND CONCLUSIONS}

Archaeologists have always favored the sense of sight over the other four senses. Typically, archaeology has emphasized vision to examine artifacts, features, architecture, landscapes, and other items relevant to ancient peoples. In recent decades, some archaeologists have investigated how ancient people may have manipulated sound in the built environment, or took advantage of acoustic phenomena of natural features (Child 2007: Garza et al. 2008; Kolar 2017; Lubman 1998; Primeau and Witt 2018; Shaw 2015; Scarre and Lawson 2006). The scale of phenomena investigated in archaeoacoustics ranges from very tiny resonance chambers, through intermediate size spaces such as buildings and hallways, including caves, and to broad open landscapes. Recently, Maya small flutes, shell trumpets, and some other artifacts, were investigated in Katz's (2018) dissertation, which offers another data source for studying archaeoacoustics in the Maya region. The most famous New World example of acoustic research in constructed spaces is at Chavín de Huantar in Peru (Kolar 2017). Scarre and Lawson (2006:3-6) describe the elaborate passageways at Chavín, and how they affect sounds in many ways. Lubman (1998) provided an example at an intermediate scale, of the echoes from handclaps at the steps of the main pyramid at Chichen Itza. The broad natural landscape scale is exemplified by acoustics within the canyon at Chaco, New Mexico (Primeau and Witt 2018). Garza et al. (2008) consider a wide range of informal-to-formal studies of Maya acoustics, and suggest standards for future investigations. Significant issues in archaeoacoustics, and suggested standards, are also available in Scarre and Lawson (2006).

The sizes of Maya sweatbaths vary in a significant way. The monumental ones at the Classic-period lowland Maya sites, such as Piedras Negras, average about $12 \mathrm{~m}^{2}$ in internal space. The internal space for the sweatbath at El Paraiso is about the same, at 10-12 $\mathrm{m}^{2}$ (Kidder and Shook 1959). Even though it is at a small village, the Cerén sweatbath featured $11.6 \mathrm{~m}^{2}$ of internal space. Others were smaller, with $8.8 \mathrm{~m}^{2}$ at Los Cimientos (Ichon 1977) and only $2.7 \mathrm{~m}^{2}$ at the tiny rural structure outside of Palenque (Webster 2018:5). Thus, the variation in Classic-period Maya sweatbaths can be seen as a kind of "urban-to-rural" continuum, from the big cities, to a village, and to a tiny one servicing a single household. The latter is more the size of sweatbaths of recent centuries, connected to individual households (Shaw 2015).

No matter what the size of sweatbaths, certain activities evidently took place in all sizes, and from all periods up to the present (Child 2006; Shaw 2015). Physical cleansing was commonly done by sweating inside, and rinsing off after leaving. Medicinal activities were frequent, as they still are today (Child 2006; Shaw 2015). Cleansing regularly took on symbolic and religious aspects (Miller and Taube 1997). Shaw (2015:80) suggested that Ixchel (Goddess O) and Itzam K'an Ahk (God N) were the female and male deities, respectively, of the sweatbath, at least with the monumental ones from the cities. Goddess $\mathrm{O}$ was a grandmother creator deity, and the warm moist sweat chamber relates to 
the fertile womb of Mother Earth (Child 2006). He also states God $\mathrm{N}$ was a grandfather creator deity, and associated with the fire that initiates the heating.

Two different kinds of rituals were identified by Child (2007) for the monumental sweatbaths, and they may well apply to the Cerén sweatbath, and perhaps to the small and the more recent ones. Midwives assisting in pregnancy through childbirth, and restoring equilibrium, along with the symbolism of water flowing out the entryway, were frequent female phenomena within the sweatbaths. Transformation rites were the other kind of ritual, where males or females of any age underwent a change of life phase, or even a rebirth into a new life. Given the research discovery of the Cerén temazcal replica powerfully affecting male voices, we believe that male-led ceremonies were frequently engaged in, and may have been a deliberate objective in the construction of the facility.

Of all the earthen architectural buildings of Cerén, the domed temazcal has attracted the most attention by visitors and scholars. It is strikingly different from all other buildings at Cerén, in that it has a double roof, i.e., an earthen dome, and a thatch roof above it, to protect the dome. It was designed so one cannot stand up in it. It did provide heat and humidity for perspiration and perhaps other bodily effects. It could provide darkness at noon. And, of great importance, it fundamentally altered sounds generated inside it, for the perception of the occupants. Cerénians' experiences of sounds within the temazcal would have been utterly different from their experiences of sounds in the outdoors, or in earthen architecture buildings with absorptive thatch roofs.

We believe the temazcal must have had antecedents. Moreover, at its time, it must have been one of many hundreds or even thousands of others in areas of earthen construction. So far, this is the only one to survive sufficiently intact to understand its construction and morphology, and create a precise replica to explore its acoustic effects. We suspect the acoustic effects that were achieved were not accidental, but more likely were quite deliberate. The issue of intentionality is one of the most challenging in archaeoacoustics. In this case, we favor deliberate construction for its acoustic effects, in part because of the uniqueness of its morphology within the village, and also the challenge of its construction. It probably reflects many generations of antecedents in the southeast Maya area, and perhaps many centuries. Unfortunately, the chances of finding many, or any, of those probable antecedents are not good. Once the protective thatch roof above earthen architecture is gone, the structure disintegrates rapidly by the effects of rain, sun, and wind.

The Cerén temazcal is not the small, family-oriented sweatbath of the Maya today, because it easily seated a dozen people, and probably was used for a wide variety of functions by different households and groups within the community. A 1:1 scale replica was constructed in the public area of the archaeological park so visitors could inspect it and enter it. Upon entering, many people noted how fundamentally it changed their voices. To investigate the acoustics, two recordings were made. The first, with a Panasonic DSC RX100M4, was of a male speaking voice outside, then inside, then back outside the structure. The second recorded the results of a balloon burst with a professional acoustic instrument. The remarkable changes became clear with both recordings, as "room resonances" were strikingly amplified, while other frequencies were suppressed. The nonfavored frequencies, the high tones, faded out quite quickly. The low tones persist and were amplified as standing waves.

The analyses of both recordings divulge the primary standing wave at $64 \mathrm{~Hz}$ from a spoken voice. That frequency is so low that a basso singer can barely achieve it. It is clear that the acoustic landscape within the temazcal fundamentally enhances mature male voices, but not mature female voices or those of children. One's speculative imagination is triggered by this realization. The resonant lowering and strengthening of the male voice may have enhanced the efficacy of the man or men in charge. The effect of a shaman/diviner upon a client could have been much more powerful. Likewise an elder in an educational or disciplinary mode could have been more effective. A rite of passage could have been enhanced. A curing ceremony could have invoked the supernatural more compellingly.

Most gender-oriented publications on Maya sweatbath use understandably emphasize women, because it symbolizes the womb of the earth mother, and was used to assist females with pregnancy, childbirth, and afterward. We suggest the Cerén sweatbath was so used, frequently. Here we further suggest that the acoustic effect on mature male voices was deliberate. We believe that archaeologists have underestimated male utilizations of the sweatbath, particularly for transformation rites.

\section{RESUMEN}

Los arqueólogos han dependido casi exclusivamente de la vista entre los cinco sentidos humanos (vista, sonido, olfato, tacto y sabor) para investigar arquitectura, rasgos y artefactos. En épocas recientes los investigadores han explorado como la gente del pasado pudo experimentar el sonido, ya que era un componente esencial en las experiencias vividas en las sociedades antiguas y recientes. Los espacios construidos natural y culturalmente tenían propiedades acústicas que exaltaban eventos sociales, políticos, económicos y rituales. Este artículo investiga a través del lente de la arqueoacústica el domo del temascal de tierra que los residentes construyeron en Joya de Cerén durante el VII siglo d.C. Su particularidad en la aldea maya del periodo clásico en El Salvador atrae considerable interés debido a su extraordinaria preservación y forma distintiva. Afortunadamente, en el 2012 construyeron una réplica precisa para el acceso público. A través de los años los visitantes que entran a la réplica notan cómo sus voces se alteran significativamente en el interior. Para evaluar científicamente estas observaciones, dos grabaciones de sonido se hicieron y analizaron acústicamente. El domo de tierra, paredes bajas y superficies reflectantes causan "frecuencias preferenciales" que se mantienen por largo tiempo, mientras otras frecuencias no favorables desaparecen rápidamente. La resonancia predominante es de 64 hertz, un tono tan bajo que los cantantes apenas lo logran. La morfología interna acentúa considerablemente las voces de los hombres maduros, pero no las de sonidos más altos como de niños o mujeres maduras. Los efectos acústicos dentro del temascal son significativamente diferentes de otros edificios con techos de zacate ya que los techos de zacate son absorbentes del sonido. El ambiente acústico puede haber sido utilizado por hombres para adivinación, curas o ritos de pasaje y otras funciones, algunas de las cuales no han sido consideradas con anterioridad. Aquí se exploran nuevas teorías sobre cómo el baño sauna era vital a toda la comunidad por la naturaleza de la experiencia vivida en un espacio de acción cargado socialmente. 


\section{ACKNOWLEDGMENTS}

We heartily thank Michael Thomason for his insightful analysis of the first recording, and for his continued support for this further analysis. His suggestions for further research on the acoustics of this temazcal replica point the way into the future. We thank Roberto Gallardo for translating the abstract, and the summary and conclusions sections. Three anonymous

\section{REFERENCES}

Beaudry-Corbett, Marilyn, Scott Simmons, and David Tucker

2002 Ancient Home and Garden: The View from Household 1 at Cerén. In Before the Volcano Erupted: The Ancient Cerén Village in Central America, edited by Payson Sheets, pp. 45-57. University of Texas Press, Austin.

Child, Mark

2006 The Archaeology of Religious Movements: The Maya Sweatbath Cult of Piedras Negras. Ph.D. dissertation, Department of Anthropology, Yale University, New Haven.

2007 Ritual Purification and the Ancient Maya Sweatbath at Palenque. In Palenque: Recent Investigations at the Classic Maya Center, edited by Damien Marken, pp. 233-264. Altamira Press, Lanham.

Cresson, Frank

1938 Maya and Mexican Sweat Houses. American Anthropologist 40: $88-102$.

Desantes, Nuria

2014 La arquitectura del baño de vapor en la cultura maya. Estudios de cultura maya 44:11-40.

Dixon, Christine C.

2013 Farming and Power: Classic Period Maya Manioc and Maize Cultivation at Cerén, El Salvador. Ph.D. dissertation, Department of Anthropology, University of Colorado, Boulder.

Domenici, Davide, Lorenzo Zurla, Arianna Campiani, and Thomas Whiting

2019 Banos de vapor en sitios arqueológicos Zoques. Nuevos datos desde el occidente de Chiapas. Estudios de cultura maya 52:45-79.

Dull, Robert, John Southon, and Payson Sheets

2001 Volcanism, Ecology and Culture: A Reassessment of the Volcan Ilopango TBJ Eruption in the Southern Maya Realm. Latin American Antiquity 12:25-44.

Dull, Robert, John Southon, Stefan Kutterolf, Armin Freundt, David Wahl, and Payson Sheets

2010 Did the TBJ Ilopango Eruption Cause the AD 536 Event? American Geophysical Union Fall Meeting Abstracts 1:2370.

Dull, Robert, John Southon, Steffen Kutterolf, Kevin J. Anchukaitis, Armin Freundt, David B. Wahl, Payson Sheets, Paul Amaroli, Walter Hernandez,

Michael C. Wiemann, and Clive Oppenheimer

2019 Radiocarbon and Geologic Evidence Reveal Ilopango Volcano as Source of the Colossal 'Mystery' Eruption of 539/40 CE. Quaternary Science Reviews 222:105855.

Fletcher, Neville, and Thomas Rossing

1998 The Physics of Musical Instruments. Springer Verlag, New York.

Forsyth, Michael

1985 Buildings for Music. The Architect, the Musician, and the Listener from the Seventeenth Century to the Present Day. MIT Press, Cambridge.

Garza, Clara, Andres Medina, Pablo Padilla, Alejandro Ramos, and

Francisca Zalaquett

2008 Arqueoacústica maya: La necesidad del estudio sistemático de efectos acústicos en sitios arqueológicos. Estudios de cultura maya 32:63-87.

Groark, Kevin

1997 To Warm the Blood, to Warm the Flesh: The Role of the Steambath in Highland Maya Ethnomedicine. Journal of Latin American Lore 20:3-96.

Handel, Stephen

1995 Timbre Perception and Auditory Object Identification. In Hearing: Handbook of Perception and Cognition, edited by Brian C.J. Moore, pp. 425-461. Academic Press, San Diego.

Houston, Stephen

1996 Symbolic Sweatbaths of the Maya: Architectural Meaning in the Cross Group at Palenque, Mexico. Latin American Antiquity 7: 132-151. reviewers contributed constructive critiques and many suggestions, considerably improving this manuscript. Many librarians at the University of Colorado have been very helpful in tracking down and making available relevant literature, in spite of the libraries being locked shut because of the Coronavirus infection of 2020. Nancy Gonlin greatly improved the text.

2000 An Archaeology of the Senses: Perception and Cultural Expression in Ancient Mesoamerica. Cambridge Archaeological Journal 10:261-294.

Ichon, Alain

1977 A Late Postclassic Sweathouse in the Highlands of Guatemala. American Antiquity 42:203-209.

International Standards Organization

2009 ISO 3382-1:2009(E), Part 1: Performance Spaces. International Standards Organization, Geneva, Switzerland.

Katz, Jared

2018 Gentle Flutes and Blaring Horns: An Analysis of Ancient Maya Music and Musical Instruments in Daily and Ceremonial Activities. Unpublished Ph.D. dissertation, Department of Anthropology, University of California Riverside, Riverside.

Kidder, Alfred, and Edwin Shook

1959 A Unique Maya Sweathouse, Guatemala. Amerikanistische Miszellen. Mitteilungen aus dem Museum fur Volkerkunde 25:70-74.

Kolar, Miriam

2017 Sensing Sonically at Andean Formative Chavín de Huántar, Perú. Time and Mind 10:39-59.

Long, Marshall

2006 Architectural Acoustics. Elsevier Academic Press, San Diego.

Lubman, David

1998 Archaeological Acoustic Study of Chirped Echo from the Mayan Pyramid at Chichén Itza. Journal of the Acoustical Society of America 104:1763.

McCafferty, Sharisse, and Geoffrey McCafferty

2008 Back to the Womb: Caves, Sweatbaths, and Sacred Water in Ancient Mesoamerica. In Flowing through Time: Exploring Archaeology through Humans and Their Aquatic Environments, edited by Larry Steinbrenner, Beau Cripps, Jim Carr, and Metaxia Georgopulos, pp. 26-33. University of Calgary Press, Calgary.

McKee, Brian

2002a Household 2 at Cerén: The Remains of an Agrarian and Craft-oriented Corporate Group. In Before the Volcano Erupted: The Ancient Cerén Village in Central America, edited by Payson Sheets, pp. 58-71. University of Texas Press, Austin.

2002b Structure 9: A Precolumbian Sweat Bath at Cerén. In Before the Volcano Erupted: The Ancient Cerén Village in Central America, edited by Payson Sheets, pp. 89-96. University of Texas Press, Austin.

Miller, Catherine

2013 Earth, Water, Sky: The Liminal Landscape of the Maya Sweatbath. Unpublished Ph.D. dissertation, Department of Anthropology, Virginia Polytechnic University, Blacksburg.

Miller, Mary, and Karl Taube

1997 An Illustrated Dictionary of the Gods and Symbols of Ancient Mexico and the Maya. Thames and Hudson, London.

Moyes, Holley

2019 Capturing the Forest: Ancient Maya Ritual Caves as Built Environments. In Approaches to Monumental Landscapes of the Ancient Maya, edited by Brett Houk, Barbara Arroyo, and Terry Powis, pp. 314-334. University Press of Florida, Gainesville.

Olson, Jan Marie

2021 The Heat of the Night: Duality in Aztec Health and Nocturnal Healing Activities with a Focus on the Temazcal. In Night and Darkness in Ancient Mesoamerica, edited by Nancy Gonlin and David M. Reed. University Press of Colorado, Louisville. In press.

Primeau, Kristy, and David Witt

2018 Soundscapes in the Past: Investigating Sound at the Landscape Level. Journal of Archaeological Science Reports 19:875-885. 
Sandstrom, Alan

2005 The Cave-Pyramid Complex among the Contemporary Nahua of Northern Veracruz. In The Maw of the Earth Monster: Mesoamerican Ritual Cave Use, edited by James Brady and Keith Prufer, pp. 35-68. University of Texas Press, Austin.

Scarre, Chris

2006 Sound, Place, and Space: Towards an Archaeology of Acoustics. In Archaeoacoustics, edited by Chris Scarre and Graeme Lawson, pp. 1-10. Oxbow Press, Oxford.

2006 Archaeoacoustics. Oxbow Press, Oxford.

Shaw, Justine (editor)

2015 The Maya of the Cochuah Region: Archaeological and Ethnographic Perspectives on the Northern Lowlands. University of New Mexico Press, Albuquerque.

Sheets, Payson

2006 The Cerén Site: An Ancient Village in Central America Buried by Volcanic Ash. 2nd ed. Thomson Learning, Belmont.
Sheets, Payson (editor)

2002 Before the Volcano Erupted: The Ancient Cerén Village in Central America. University of Texas Press, Austin.

Sheets, Payson, and Michael Thomason

2021 The Sounds in the Dark of the Temazcal at Cerén, El Salvador. In Night and Darkness in Ancient Mesoamerica, edited by Nancy Gonlin and David M. Reed. University Press of Colorado, Louisville. In press.

Tilley, Christopher

2008 Body and Image: Explorations in Landscape Phenomenology. Left Coast Press, Walnut Creek.

Webster, David

2018 A Rural Sweat Bath at Piedras Negras, Guatemala. Electronic document, https://anth.la.psu.edu/documents-new/copy_of_Webster Sweatbath.pdf, accessed April 28, 2020

Zalaquett, Francisca, and Dulce Espino

2019 Flautas triples de Jaina y Copan. Un estudio arqueoacustico. Ancient Mesoamerica 30:419-438. 